\title{
Azadirachta indica: Antibacterial Activity of Neem Against Different Strains of Bacteria and their Active Constituents as Preventive in Various Diseases
}

\author{
Oscar Herrera-Calderon ${ }^{1, *}$, Kainat Ejaz², Mahnoor Wajid ${ }^{3}$, Muzzamil Shehzad ${ }^{4}$, Johnny Aldo Tinco-Jayo5, \\ Edwin Enciso-Roca ${ }^{5}$, Cesar Franco-Quino ${ }^{6}$, Ricardo Ángel Yuli-Posadas ${ }^{7}$, Victor Chumpitaz-Cerrate ${ }^{8}$
}

\begin{abstract}
Oscar Herrera-Calderon ${ }^{1, *}$, Kainat Ejaz $^{2}$, Mahnoor Wajid ${ }^{3}$, Muzzamil Shehzad ${ }^{4}$, Johnny Aldo TincoJayo ${ }^{5}$, Edwin Enciso-Roca ${ }^{5}$, Cesar Franco-Quino ${ }^{6}$, Ricardo Ángel Yuli-Posadas ${ }^{7}$, Victor ChumpitazCerrate $^{8}$
\end{abstract}

'Faculty of Pharmacy and Biochemistry, Universidad Nacional Mayor de San Marcos, Lima, PERU.

${ }^{2}$ Department of Biochemistry, Sardar Bahadur Khan Women's University,

Balochistan, Pakistan.

${ }^{3}$ Department of Biotechnology, University of Central Punjab, Lahore, PAKISTAN.

${ }^{4}$ Department of Biotechnology, Faisalabad Institute of Research Science and Technology Faisalabad, PAKISTAN.

${ }^{5}$ Faculty of Health Sciences, Universidad Nacional de San Cristóbal de Huamanga, Ayacucho, PERU.

${ }^{6} \mathrm{~S}$ chool of Public Health and Administration, Universidad Peruana Cayetano Heredia, Lima, PERU.

'Universidad Continental, Huancayo, PERU. ${ }^{8}$ Laboratory of Pharmacology, Universidad Científica del Sur, Lima, PERU.

\section{Correspondence}

\section{Dr. Oscar Herrera Calderon}

Jr Puno 1002, Cercado de Lima, Faculty of Pharmacy and Biochemistry, Universidad Nacional Mayor de San Marcos, Lima, PERU.

Phone no: +51956550510

E-mail: oherreraca@unmsm.edu.pe

History

- Submission Date: 01-09-2019;

- Review completed: 10-10-2019;

- Accepted Date: 31-10-2019.

DOI : 10.5530/pj.2019.11.244

Article Available online http://www.phcogj.com/N11/i6s

\section{Copyright}

(C) 2019 Phcogj.Com. This is an openaccess article distributed under the terms of the Creative Commons Attribution 4.0 International license.

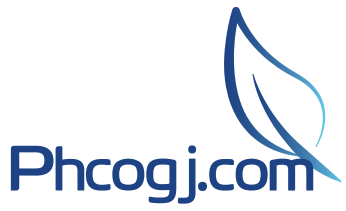

\section{ABSTRACT}

Neem has become valuable plant in the world which shows the solutions for hundreds to thousands problems. Azadirachta indica (Neem) is a rapidly growing evergreen well known tree found Pada generally in various regions of world like America, Africa and India. It has been widely used in Chinese, Ayurveda and Unani medicines across the world especially in Asians countries for the prevention and treatment of diseases. The different parts of neem plant contain biological compounds responsible for antibacterial, antiviral and antifungal activities. It is considered as safe medicinal plants and modulates the numerous biological processes without any adverse effect. Neem tree produces some active compounds which contain biological activities, parts of neem tree such as Root, bark, leaf, flower, seed and fruit together possesses biological activities. Various compounds have been obtained from various parts of neem. Biological activities of few of them have been studied. Hence, the article is aims to utilize the medicinal properties of whole neem plant in various disorders of mankind. Key words: Azadirachta indica, Antibacterial, Antifungal, Natural products, Natural antibiotics.

\section{INTRODUCTION}

Plants have many biologically active compounds which have latent for development as medicinal agents. Herbal medicines already form the basis of beneficial use in the developing countries, but of recent, there has been rise in the use of herbal medicines in the developed world. ${ }^{1}$ Plants provide an alternate approach in search for new treatments. There is a plenty of plants reputed in traditional medicine to hold protective and therapeutic properties. ${ }^{2}$ It is likely that plants will continue to be a valued source of new molecules which may, after possible chemical manipulation, provide new and improved drugs. ${ }^{3}$ Bacterial resistance to antibiotics represents a serious problem for clinicians and the therapeutic industry and great efforts are being made to reverse this trend, and one of them is the widespread screening of medicinal plants from the traditional system of medicine hoping to get some newer, safer, and more effective agents that can be used to fight infectious diseases. ${ }^{4}$

Each part of Neem tree has various medicinal properties. Non woody part of Neem such as leaf, bark, oil, flowers, fruits and seed show great properties that is Antiallergic, Antifungal, Antibiotic, Antidermatic, Antibacterial, Antiinflammatory, Insecticidal, Larvicidal, Antimalarial, Antiulcer and other biological activities. ${ }^{5}$ Some water soluble extract of Azadirachta Indica have great importance in hyperglycemia, hypolipidemia and hypotensive activities. ${ }^{6}$

\section{ANTIMICROBIAL ACTIVITY OF NEEM}

Neem has great Antimicrobial activity it contains 35 biological active compounds. Neem leaf juice and twigs are used to clean teeth and used as a tonic and people of India used to place Neem leaves in their beds, books and cupboards to prevent bugs.? A number of potent pharmaceutical compounds limnoods and triterpenoids have been isolated from the fruits and bark of neem tree.

Neem extracts and its different constituents play essential role in the inhibition of several microbes which includes viruses, fungi and bacteria. The extracts of methanol and hexane chloroform of Azadirachta indica were selected against antibacterial activity on Escherichia coli, Proteus vulgaris, Klebsiella pneumonia, Bacillus subtilis, Micrococcus luteus, Streptococcus faecalis and Enterococcus faecalis. It was revealed that methanol extract was the most effective, chloroform reasonably effective and hexane extract showed little antibacterial activity. ${ }^{8}$ The antibacterial activity of neem describes as fellow.

\section{Antibacterial action of neem}

Neem usually used in medicine and pharmaceutics. The stem and bark of Neem has great antibacterial activity against Klebsiella, Serratia species and Streptococcus. ${ }^{9}$ The methanolic extracts of Neem has antibacterial activity against Vibrio cholera and chloroform extracts against E. coli, Bacillus subtilis, Enterococcus faecalis and Streptococcus faecalis. ${ }^{10}$

Cite this article: Herrera-Calderon O, Ejaz K, Wajid M, Shehzad M, Tinco-Jayo JA, Enciso-Roca $\mathrm{E}$, et al. Azadirachta indica: Antibacterial Activity of Neem Against Different Strains of Bacteria and their Active Constituents as Preventive in Various Diseases. Pharmacog J. 2019;11(6) Suppl:1597-604. 
The extraction of neem oil has strong activity against Gram positive and Gram negative bacteria like Mycobacterium tuberculosis and streptomycin-resistant strains. Mahmood et al. (2013) determined in his study that the crude extraction of Neem has antibacterial activity against infection of eyes and ear. ${ }^{11}$ The petroleum ether and methanol extract has highest effect against Candida albicans. ${ }^{12}$

The antibacterial action of neem and guava samples against 21 strains of food endured pathogens was assessed and results of this examination recommended that neem and guava extracts have compounds holding antibacterial functions that can be beneficial to resist food endured pathogens and decomposer organisms. ${ }^{13}$ Another research was carried out to assess the antibacterial action of the leaf, seed, bark and fruit extracts of Azadirachta Indica (neem) on microbes obtain from mouth of adult and effects revealed that leaf and bark extracts possess antibacterial action against all the tested bacteria. ${ }^{14}$ Moreover, fruit and seed extract presented antibacterial action at greater concentration only.

Oil extracted from leaves, bark and seeds hold a broad range antibacterial activity against gram positive and gram negative microbes containing streptomycin-resistant mechanisms and Mycobacterium tuberculosis strains. ${ }^{15}$ The phytoconstituents like alkaloids, saponins, steroids, tannins, crude glycosides and flavonoids (Figure 1) was used for sterile action against strains of Escherichia coli, Corynebacterium bovis and Staphylococcus aureus. ${ }^{16}$

When microorganisms exposed to neem extracts their susceptibility compared with particular antibacterial. Methanol extract of neem have

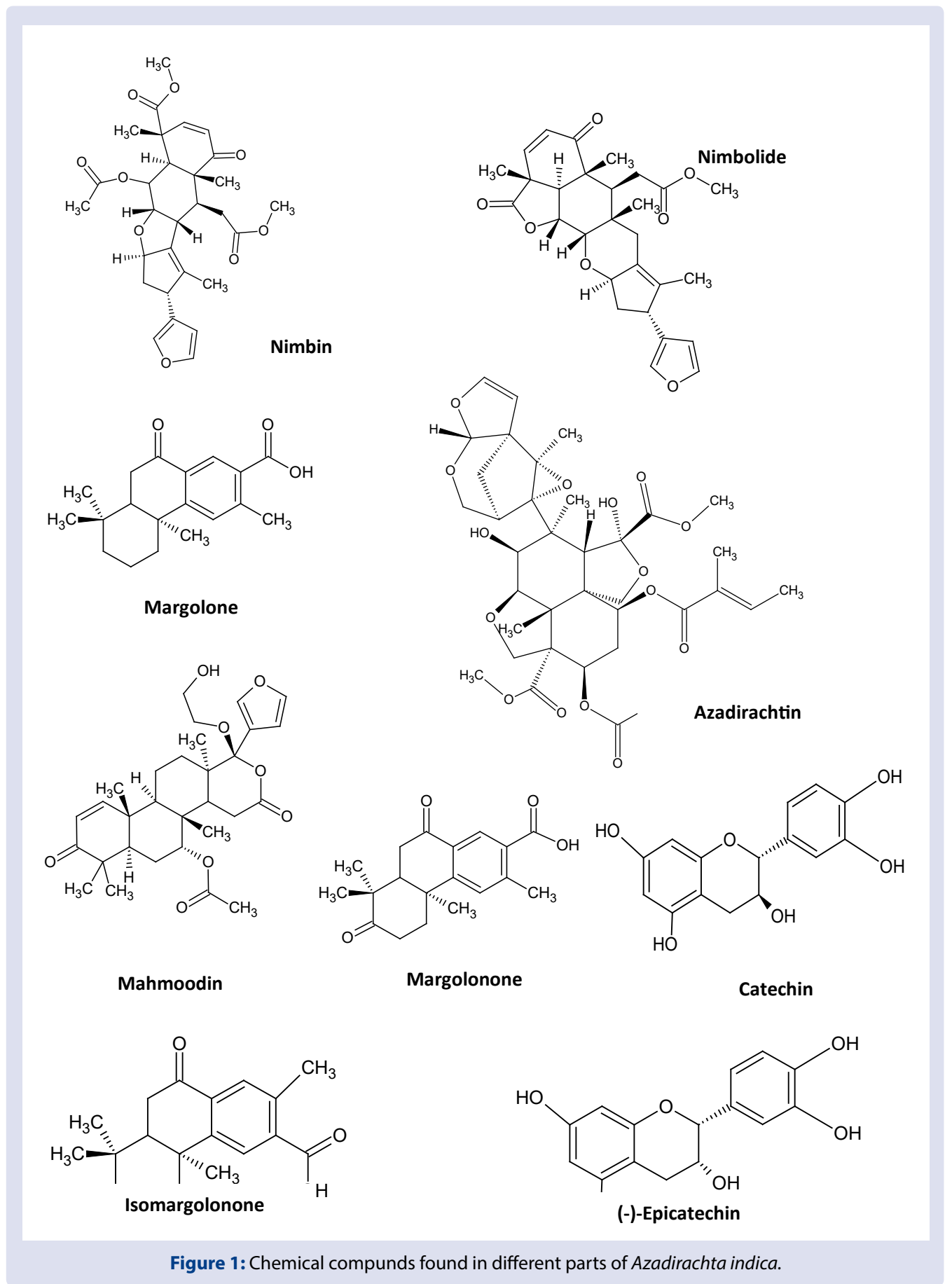


definite antibacterial activity against Bacillus subtilis $(28 \mathrm{~mm}) .{ }^{17}$ Neem oil is also found active against wide range of bacteria Bacillus pumilus, Mycobacterium tuberculosis, Staphylococcus aureus, Pseudomona vulgaris, Escherichia coli, Klebsiella pneumonae, Salmonella typhi, Enterococcus faecalis, Streptococcus dysenterae, Streptococcus salivarius, Streptococcus mutans and Streptococcus mitis. ${ }^{18}$ Azadirachta indica leaf extracts have a best anti-bacterial activity which confirmed the bioactive compounds strength and proved the usage of neem plant in major health maintenance. ${ }^{19}$

Khan et al., (1997) investigated antibacterial activity of impure neem bark extract (Azadirachta indica) tested to streptococcus sobrinus. The aqueous and acetonic extracts of bark studied on agar dishes by streptococcus sobrinus strains. ${ }^{20}$

Asthana et al., (2006) carried out antimicrobial activity against cyanobacterium Fischerella spp. isolate from neem bark. Methanolic bark extract of neem (Azadirachta indica) initiate to be active against Enterobacter aerogenes, Mycobacterium tuberculosis, Staphylococcus aureus, Salmonella typhi, Pseudomonas aeruginosa and Escherichia coli. Antimicrobial activity was assessed by a little altered Disk Diffusion Kirby Bauer method of susceptibility. ${ }^{21}$

Barua et al., (1999) stated neem (Azadirachta Indica) as antibacterial agent against pathogenic bacteria present in fish. Aqua-neem arranged from neem kernels (Azadirachta indica) which was used against four fish bacteria (Pseudomona fluorescens, Aeromonas hydrophila, Escherichia coli and Mycobacteria spp.) For the effectiveness of neem among all the bacteria tested A. hydrophila, Mycobacteria spp, and P. fluorescens. Results showed that it holds maximum sensitivity to Aquaneem (Azadiracht aindica). ${ }^{22}$

\section{Antifungal action of neem}

Azadirachta indica leaves ethanol and aqueous extracts have exhibited anti-dermatophytic activity in contrast to dermatophytes from 88 clinical separates by agar dilution technique. These studies revealed that ethanolic extracts showed more visible activity as compared to aqueous extracts. $^{23}$ Azadirachta indica methanolic and acetone extracts were tested for antifungal activities against two fungal strains i.e. Aspergillus fumigatus and Aspergillus niger. Results showed that methanol extracts of plant provide supreme antifungal activity as compared to acetone extracts. The leaf and seed extracts of neem screened for antifungal activity against dermatophytes. Azadirachta indica seed extracts Minimum inhibitory concentration (MIC) was lower than that of neem leaf extracts when tested against various species of trichophyton and Epidermatophyton floccosum. ${ }^{24}$

Antifungal activity of Azadirachta indica tested on different pathogens through different neem extracts it includes ethanolic, aqueous and ethyl acetone extracts on growth of pathogens i.e. Microsporum gypseum, Aspergillus terreus, Candida albicans, Aspergillus niger, Aspergillus fumigates and Aspergillus flavus, by using different concentrations and results showed that these leaves extracts stopped the growth of the tested pathogens (Table 1). This effect increased by increasing the concentration. ${ }^{25-31}$

\section{THERAPEUTIC EFFECTS OF NEEM AND ITS VAR- IOUS COMPONENTS IN HEALTH MANAGEMENT}

The Phyto-constituents of neem is Alkaloids, Glycosides, Flavonoids and Saponins that showed antibacterial activity against different pathogen. Some biological compounds of Neem are very effective against various insects, mites, nematodes and other plants pathogens including 25 species of Pleopetera (beetles), 10 species of Diptera (flies), 25 species of Lepidoptera (moths) and 9 species of Orthoptera (locusts). Leaf and fruits extracts have been tested on different pest with desire results some parts of neem tree are use as physical ailments that are heart disease, Diabetes, Blood disorder, Digestive and nervous disorder, parasites and possibly cancer. Particular study on Neem bark extract concluded that it helps to reduce and heal acid reflux and Gastric ulcer. ${ }^{32}$

Active components play role in cure of diseases through activation of antioxidants enzymes, by breaking the cell wall of bacteria and act as chemo preventive through regulating cellular pathways. Different pharmacological activities of neem are discussed in detail below.

\section{Antimalarial activity}

Ball shaped wood scrapes that is saturated in 5 percent oil of neem (Azadirachta indica) diluted with acetone and in 45 days the propagation of Anopheles stephensi and Aedes aegypti were organized, when it is placed in water storage overhead containers. ${ }^{33}$ Growth of plasmodium falciparum inhibited by the compound nimbolide isolated from neem extracts that shows the antimalarial activity. ${ }^{34}$ Neem seeds oil possess gedunin which also showed antimalarial activity ${ }^{35}$ Leaves and bark aqueous and alcohol extracts are very effective antimalarial agents, especially on resistant strains chloroquine. ${ }^{36}$

\section{Antitumor and antiviral activity}

Europe, Japan and Indian scientist found the compounds limonoids and polysaccharides present in neem seed oil. Neem leaves and bark reduced cancers and tumors and also very effective against lymphocytic leukemia. Leaf extracts mitotic inhibition activity was detected. Several results have also showed the significant antiviral effect of neem leaf aqueous extracts against Small Pox, Fowl Pox, Polio and HSV as evaluated by virus inhibition assay (98100). Neem Aqueous leaf extracts and also some oils of neem fraction (Nim-76) showed antiviral action against Polio Viruses and HIV. ${ }^{37}$

\section{Table 1: Antibacterial activity in vitro of Azadirachta indica reported in PUBMED CENTRAL.}

\begin{tabular}{|c|c|c|c|c|}
\hline Azadirachta indica & Microorganism & MIC & $\mathrm{MBC}$ & Reference \\
\hline oil & Helicobacter pylori & $25-51 \mu \mathrm{g} / \mathrm{mL}$ & $43-68 \mu \mathrm{g} / \mathrm{mL}$ & {$[26]$} \\
\hline Leaves ethanolic extract & Methicillin-resistant Staphylococcus aureus & $31.25-125 \mathrm{mg} / \mathrm{mL}$ & $250-500 \mathrm{mg} / \mathrm{mL}$ & {$[27]$} \\
\hline \multirow{3}{*}{ Bark extract } & Staphylococcus aureus & \multirow{3}{*}{$500-1000 \mu \mathrm{g} / \mathrm{mL}$} & \multirow{3}{*}{ n.d. } & \multirow{3}{*}[28]{} \\
\hline & $\begin{array}{c}\text { Enterococcus faecalis } \\
\text { Pseudomona aeruginosa }\end{array}$ & & & \\
\hline & Pseudomona mirabilis & & & \\
\hline Neem oil nanoemulsion & Vibrium vulnificus & $6 \mathrm{mg} / \mathrm{mL}$ & n.d & {$[29]$} \\
\hline Leaves ethanolic extract & Streptococcus mutans & $6.25 \mathrm{mg} / \mathrm{mL}$ & n.d. & {$[30]$} \\
\hline \multirow{4}{*}{ Leaves methanol extract } & Streptococcus mutans & $125 \mu \mathrm{g}$ & $250 \mu \mathrm{g}$ & \multirow{4}{*}[31]{} \\
\hline & Enterococcus faecalis & $500 \mu \mathrm{g}$ & $1 \mathrm{mg}$ & \\
\hline & Staphylococus aureus & $250 \mu \mathrm{g}$ & $500 \mu \mathrm{g}$ & \\
\hline & Candida albicans & n.a. & n.a. & \\
\hline
\end{tabular}

MIC: minimum inhibitory concentration; MBC.: minimum bactericidal concentration; n.d.: not determined; n.a: no activity 


\section{Anti-inflammatory, antipyretic and analgesic activities}

The stem bark chloroform extracts of neem show efficiency against carrageenan -which induced paw edema in rats and ear inflammation in mouse. Bark extracts is also used to treat inflammatory stomatitis in children. Neem oil holds antipyretic activity, its leaves extracts showed antipyretic effect when injected into male rabbits. Various extract effects as Antipyretic and Anti-inflammatory have been studied. ${ }^{38}$

\section{Male antifertility activity}

Neem leaf extracts and seed oil (NSO) used as a great spermicide and also prevented spermatogenesis, lowered sperm mobility, number and pausing of fertility. Further, NSO keeps abortifacient and antiimplantation properties. The neem oil extracts carry the spermicidal activity against rhesus monkey and humans. Biopsy of vagina reveals no side effects, while radio isotopes examination showed non-antiovulatory and non-absorption in vagina. These all findings supported neem oil formulation "sensal" which is used as strong contraceptive in India. ${ }^{39}$

\section{Antiulcer activity}

Nimbidin was known to be responsible for antiulcer effect which prevents acetylsalicylic acid, omethacin, serotonin-induced gastric lesions and duodenal ulcers or histamine. ${ }^{40}$ Azadirachta indica (neem) leaf extracts shows antiulcer effect and mucus depletion inhibition and most cell defragmentation as possible mechanism. Researcher isolated the phenolic glycoside as an active constituent. Furthermore, Azadirachta indica offers good option for active antiulcer and harmless drug. ${ }^{41}$

\section{Antioxidant compounds}

The process, by which free radicals are formed, is a normal task of body but the molecules formed in a result are not stable and cause damage of other cells. A number of disorders like cardiovascular disease, health of eye and muscular degeneration and even cancer occurrence due to presence of free radicals' high quantity in a body. Neem boosts the antioxidant level and protects against chemically induced carcinogens and liver damage.

Diabetes: Neem with its extremely bitter taste and properties has been used in disorders caused due to overeating sweets. The studies on neem focused on its hypoglycemic effects.

Liver functions: It protects the liver damage, liver in turn help in cleaning the blood. Neem leaf reduces chemically induced liver damage by regulating level of serum marker enzymes and boosts count of antioxidants, like some of them present in vitamin $\mathrm{C}$ and $\mathrm{E}$. which prevent damage by neutralizing free radicals.

Stress: Neem leaf extracts low doses have relaxing effects. The effect fades at high doses, 400 or 800 milligrams per kilograms of body weights. It's also lesser anxiety and stress.
Vitiligo: It's an autoimmune disorder that causes skin patches to lose its color. Neem leaves dosage is of four grams for three times per day, mostly taken before the meal. Neem oil applied to the affected area for the aid in setback of discoloration.

AIDS: Neem may help in search for preventing and therapy of AIDS It may probable to treat by intake of neem leaf extracts or the complete leaf or by drinking a neem tea. ${ }^{42}$

Anticancer action: Cancer is a main health issue across the world and multifactorial disease. The change in molecular pathways shows role in the improvement and advancement of cancer. The handling part based on allopathic which is operative on one side but also have some adverse effects on normal cell. Previous studies stated that plants different constituents inhibit growth of malignant cells through variation of cellular propagation, apoptosis, suppression of tumor and other molecular pathways. Neem oil have different components limonoids, which inhibit mutagenic effect of 7, 12-dimethylbenz(a)anthracene. ${ }^{43}$ A research was performed to evaluate the cytotoxic effect of nimbolide present in leaves and flowers on human choriocarcinoma (BeWo) cells and results revealed that nimbolide treatment resulted in dose and growth inhibition of BeWo cells with 2.01 IC50 values and $1.19 \mu \mathrm{M}$ for7-24h, correspondingly. ${ }^{44-48}$

\section{Biological compound of Azadirachta indica (Neem)}

Neem contain different biological compound that act against different activities (Table 2).

\section{Medicinal properties of Neem (Azadirachta indica)}

Neem show great properties of medicine. Their non woody parts like flowers, leaves, bark, fruits and seeds perform different functions. Neem has antibacterial, Antifungal and different others properties. ${ }^{49}$

Some medicinal properties of Neem tree as given below (Table 3).

\section{Mechanism of action of active compounds}

Mechanism of action of active compounds of Azadirachta indica is given as,

Neem (Azadirachta indica) different parts show activity against microbes through inhibiting the growth of microbes by breakdown of cell wall. Azdirachtin, which is present in seeds of neem, is the basic constituent responsible for antifeedant activity and harmful effects in pests. Results revealed that the ethanol leaves extracts indicated antibacterial action against $S$. aureus with highest inhibition zones occurred at concentration of $100 \%{ }^{51}$

Neem character as free radical hunting action due to presence of Azadirachtin and nimbolide which showed concentration reliant antiradical hunting activity in the given order nimbolide $>$ azadirachtin $>$ ascorbate..$^{52}$

Table 2: Bioactive compounds of Azadirachta indica reported in scientific literatures.

\begin{tabular}{cccc}
\hline No. & Compound Name & Source & Biological activity \\
\hline 1 & Nimbidin & Seed oil & Anti-inflammatory \\
2 & Azadirachtin & Seed oil & Antimalarial \\
3 & Nimbin & Seed oil & Spermicidal. \\
4 & Mahmoodin & Seed oil & Antibacterial \\
6 & Margolone, mergolonone and isomargolonone & Bark & Antibacterial \\
7 & Cyclic trisulphide and cyclic tetrasulphide & Leaf & Antifungal \\
8 & Gedunine & Seed oil & Antifungal \\
9 & Polysaccharides & Bark & Anti-inflammatory. \\
10 & NB-2 peptidoglucan & Bark & Immunomodulatory.
\end{tabular}


Table 3. Tradional uses from Azadirachta indica reported in research articles.

\begin{tabular}{cc}
\hline Leaf & Leprosy, diuretic, malaria, piles, pyrexia, chicken pox, smallpox and remove toxins, cleanse blood [50, 51]. \\
Root & Used as a disinfectant, antimicrobial and provocative diseases. [50,51]. \\
Seed & Mosquito coils, Rheumatism, anthelmintic, antileprotic [50, 51]. \\
$\begin{array}{c}\text { Seed oil } \\
\text { Fruit }\end{array}$ & Used as an Antiseptic for ulcers and useful for skin diseases like ringworm and scabies, fever and leprosy, and for antibacterial use. [50, 51]. \\
Bark & Fruit extracts of neem beneficial for Insecticidal, diabetes, constipation and anthelmintic [52]. \\
Stembark & Use as a cure for fever [51]. \\
Flower & Anti-cancerous [50, 51, 52]. \\
Young branch & Cough and non-toxic [50, 51, 52]. \\
\hline
\end{tabular}

\section{CONCLUSION}

Azadirachta indica (Neem) plant acts as a medicinal plant have been found effective in the treatment of bacterial, fungal, viral and other diseases and revealed the antibacterial, antifungal, antiviral, antimalarial, antiulcer and other biological activities. Due to increasing antibiotic resistance in microorganisms and side effects of synthetic antibiotics neem plant are now growing popularity in the treatment of many infections. Neem plant is considered as clinically effective and safer alternatives to the synthetic antibiotics. Extensive research in the area of isolation and characterization of the active principles of neem plant is essential so that better, safer and cost effective drugs for curing various diseases and infections can be developed.

\section{DISCLOSURE}

The authors report no conflicts of interest in this work.

\section{FINANCIAL SUPPORT AND SPONSORSHIP}

Nil

\section{ACKNOWLEDGEMENT}

Cesar Franco-Quino is a doctoral student studying an Epidemiological Researcher Doctorate at Universidad Peruana Cayetano Heredia under FONDECYT/CIENCIAACTIVA scholarship EF033-235-2015 and supported by training grant D43 TW007393 awarded by Fogarti International Center of the US National Institutes of Health.

\section{REFERENCES}

1. Moga MA, Bălan A, Anastasiu CV, Dimienescu OG, Neculoiu CD, Gavri * C. An Overview on the Anticancer Activity of Azadirachta indica (Neem) in Gynecological Cancers. Int J Mol Sci. 2018;19(12):3898.

2. Alzohairy MA. Therapeutics Role of Azadirachta indica (Neem) and Their Active Constituents in Diseases Prevention and Treatment. Evid Based Complement Alternat Med. 2016; 2016: 7382506.

3. Paula AR, Ribeiro A, Lemos FJA, Silva CP, Samuels RI. Neem oil increases the persistence of the entomopathogenic fungus Metarhizium anisopliae for the control of Aedes aegypti (Diptera: Culicidae) larvae. Parasit Vectors. 2019;12(1):163

4. Zingue S, Kamga Silihe K, Fouba Bourfane I, et al. Potential of Regular Consumption of Cameroonian Neem (Azadirachta indica L.) Oil for Prevention of the 7,12-Dimethylbenz(a)anthracene-Induced Breast Cancer in High-Fat/ Sucrose-Fed Wistar Rats. Evid Based Complement Alternat Med. 2019. 2019:2031460.

5. Campos EV, de Oliveira JL, Pascoli M, de Lima R, Fraceto LF. Neem Oil and Crop Protection: From Now to the Future. Front Plant Sci. 2016; 7:1494.

6. Aslam F, Rehman KU, Asghar M, Sarwar M. Antibacterial activity of various phytoconstituents of Neem. Pak J Agri Sci. 2009;46(3):209-213.

7. Banerjee S, Kim LM, Shariff M, Khatoon H, Yusoff SM. Antibacterial activity of neem (Azadirachta indica) leaves on Vibrio spp. Isolated from cultured shrimp. Asian J Animal Veterinary Adv, 2012;3923:1-7.

8. Divya Kumari P, Shenoy SM, Khijmatgar S, Chowdhury A, Lynch E, Chowdhury CR. Antibacterial activity of new atraumatic restorative treatment materials incorporated with Azadirachta indica (Neem) against Streptococcus mutans. J Oral Biol Craniofac Res. 2019;9(4):321-5.
9. Mafou-Sonhafouo V, Kana JR, Nguepi-Dongmo K. Effects of graded levels of Azadirachta indica seed oil on growth performance and biochemical profiles of broiler chickens. Vet Med Sci. 2019;5(3):442-50.

10. Shah FM, Razaq M, Ali A, Han P, Chen J. Comparative role of neem seed extract, moringa leaf extract and imidacloprid in the management of whea aphids in relation to yield losses in Pakistan. PLoS One. 2017;12(9):e0184639.

11. Mahmoud DA, Hassanein NM, Youssef KA, Zeid A. Antifungal activity of different neem leaf extracts and the nimonol against some important human pathogens. Braz J Microbiol. 2011;42(3):1007-16.

12. Bhuiyan MM, Nishimura M, Matsumura S, Shimono T. Antibacterial effects of the crude Azadirachta indica Neem bark extract on Streptococcus sobrinus. Pediatr Dent J. 1997;7(1):61-4.

13. Bohnenstengel FI, Wray V, Witte L, Srivastava RP, Proksch P. Insecticidal meliacarpins (C-seco limonoids) from Melia azedarach. Phytochemistry. 199;50(6):977-82.

14. Chauhan S, Jindal M, Singh P, Tewari S. Antimicrobial Potential of Aqueous, Methanolic and Ethanolic Extracts of Azadirachta indica against Bacterial Pathogens Isolated from Urinary Tract Infection Patients. Int J Curr Microbio App Sci. 2015;4(7):211-4.

15. Cowan MM. Plant products as antimicrobial agents. Clin Microbiol Rev. 1999;12(4):564-82

16. Debjit B, Jitender $Y$, Tripathi KK, Kumar KS. Herbal remedies of Azadirachta indica and its medicinal application. J Chem Pharm Res. 2010;2(1):62-72.

17. Dharmani P, Palit G. Exploring Indian medicinal plants for antiulcer activity Indian J Pharmacol. 2006;38(2):95.

18. Dholi SK, Raparla R, Mankala SK, Nagappan K. In vivo Antidiabetic evaluation of Neem leaf extract in alloxan induced rats. J Appl Pharm Sci. 2011;1(4):100-5

19. Dua VK, Nagpal BN, Sharma VP. Repellent action of neem cream against mosquitoes. Indian J Malariol. 1995;32(2):47-53.

20. Khan AV, Ahmed QU, Mir MR, Shukla I, Khan AA. Antibacterial efficacy of the seed extracts of Melia azedarach against some hospital isolated human pathogenic bacterial strains. Asian Pac J Trop Biomed. 2011;1(6):452-5.

21. Asthana RK, Srivastava A, Singh AP, Singh SP, Nath G, Srivastava R, et al Identification of an antimicrobial entity from the cyanobacterium Fischerella sp. isolated from bark of Azadirachta indica (Neem) tree. J Appl Phycol. 2006; 18(1):33-9

22. Barua DR, Basavanna JM, Varghese RK. Efficacy of Neem Extract and Three Antimicrobial Agents Incorporated into Tissue Conditioner in Inhibiting the Growth of C. Albicans and S. Mutans. J Clin Diagn Res. 2017;11(5):ZC97-101.

23. Jerobin J Makwana P Kumar RS, Sundaramoorthy R, Mukherjee A Chandrasekaran $\mathrm{N}$. Antibacterial activity of neem nanoemulsion and its toxicity assessment on human lymphocytes in vitro. Int J Nanomedicine. 2015;10(Suppl 1):77.

24. Kelmanson JE Jäger, AK, van Staden J. Zulu medicinal plants with antibacterial activity. J Ethnopharmacol. 2000;69(3):241-6.

25. Khalid SA, Duddeck H, Gonzalez-Sierra M. Isolation and characterization of an antimalarial agent of the neem tree Azadirachta indica. Journal of natural products. 1989;52(5):922-7.

26. Blum FC, Singh J, Merrel DS. In vitro activity of neem (Azadirachta indica) oil extract against Helicobacter pylori. J Ethnopharmacol. 232;(25):236-43.

27. Zihadi $\mathrm{MAH}$, Rahman $\mathrm{M}$, Talukder $\mathrm{S}$, Hasan MM, Nahar $\mathrm{S}$, Sikder $\mathrm{MH}$ Antibacterial efficacy of ethanolic extract of Camellia sinensis and Azadirachta indica leaves on methicillin-resistant Staphylococcus aureus and shigatoxigenic Escherichia coli. J Adv Vet Anim Res. 2019;6(2):247-52.

28. Singaravelu S, Sankarapillai J, Sasidharn Chandrakumari A, Sinha P. Effect of Azadirachta indica Crude Bark Extracts Concentrations against Gram-Positive and Gram-Negative Bacterial Pathogens. J Pharm Bioallied Sci. 2019;11(1):33-7.

29. Jerobin J, Makwana P, Suresh Kumar RS, Sundaramoorthy R, Mukherjee A Chandrasekaran N. Antibacterial activity of neem nanoemulsion and its toxicity assessment on human lymphocytes in vitro. Int J Nanomedicine. 2015;10 Suppl 1(Suppl 1):77-86. 
30. Bodiba DC, Prasad P, Srivastava A, Crampton B, Lall NS. Antibacterial Activity of Azadirachta indica, Pongamia pinnata, Psidium guajava, and Mangifera indica and their mechanism of action against Streptococcus mutans. Pharmacogn Mag. 2018;14(53):76-80.

31. Mistry KS, Sanghvi Z, Parmar G, Shah S, Pushpalatha K. Antibacterial efficacy of Azadirachta indica, Mimusops elengi and $2 \% \mathrm{CHX}$ on multispecies dentinal biofilm. J Conserv Dent. 2015;18(6):461-6.

32. Jafari S, Saeidnia S, Ardekani MRS, Hadjiakhoondi A, Khanavi M Micromorphological and preliminary phytochemical studies of Azadirachta indica and Melia azedarach. Turk J Botany. 2013;37(4):690-7.

33. Kumar PS, Debasis M, Goutam G, Panda CS. Biological action and medicinal properties of various constituent of Azadirachta indica (Meliaceae): an overview. Ann Biol Res. 2010;1(3):24-34.

34. Maragathavalli S, Brindha S, Kaviyarasi NS, Annadurai B, Gangwar SK. Antimicrobial activity in leaf extract of neem (Azadirachta indica Linn.). Int J Sci Nat. 2012;3(1):110-3

35. Tiwari $V$, Darmani NA, Yue BY, Shukla D. In vitro antiviral activity of neem (Azardirachta indica L.) bark extract against herpes simplex virus type-1 infection. Phytother Res. 2010;24(8):1132-40.

36. Hossain MA, Al-Toubi WA, Weli AM, Al-Riyami QA, Al-Sabahi JN. Identification and characterization of chemical compounds in different crude extracts from leaves of Omani neem. J Taibah Univ Sci. 2013; 7(4):181-8.

37. Irshad $\mathrm{S}$, Butt $\mathrm{M}$, Younus $\mathrm{H}$. In-vitro antibacterial activity of two medicinal plants Neem (Azadirachta indica) and Peppermint. Int Res J Pharma. 2011;1(01):9-14.

38. Francine $U$, Jeannette $U$, Pierre RJ. Assessment of antibacterial activity of neem plant (Azadirachta indica) on Staphylococcus aureus and Escherichia coli. J Med Plants Stud. 2015;3(4):85-91.

39. Purohit A. Antifertility Efficacy of Neem Bark (Azadirachta indica A. juss.) in Male Rats. Anc Sci Life. 1999:19(1-2):21-4.

40. Ofusori DA Falana BA Ofusori AE Caxton-Martins EA Regenerative Potential of Aqueous Extract of Neem Azadirachta indica on the Stomach and Ileum Following Ethanol-induced Mucosa Lesion in Adult Wistar Rats. Gastroenterology Res. 2010;3(2):86-90.
41. Grover A Bhandari BS, Rai N Antimicrobial activity of medicinal plantsAzadirachta indica A. Juss, Allium cepa L. and Aloe vera L. Int J Pharm Tech Re. 2011;3:1059-65.

42. Ahmad A, Javed MR, Rao AQ, Husnain T. Designing and screening of universa drug from neem (Azadirachta indica) and standard drug chemicals agains influenza virus nucleoprotein. BMC Complement Altern Med. 2016;16(1):519.

43. Hao F, Kumar S, Yadav N, Chandra D. Neem components as potential agents for cancer prevention and treatment. Biochim Biophys Acta. 2014;1846(1):247-57.

44. Patki JM, Shah P. Screening of Neem extracts for microbial anti-chaperone activity by employing in vitro enzyme refolding assay. 3 Biotech. 2017;7(5):277.

45. Bhargava KP, Gupta MB, Gupta GP, Mitra CR. Anti-inflammatory activity of saponins and other natural products. Indian J Med Res. 1970;58(6):724.

46. Jones IW, DenholmAA, Ley SV, Lovell H, WoodA, Sinden RE. Sexual development of malaria parasites is inhibited in vitro by the neem extract azadirachtin, and its semi-synthetic analogues. FEMS Microbiol Lett. 1994;120(3):267-273.

47. Sharma VN Saksena KP. Sodium-nimbidinate-in vitro study of its spermicida action. Indian J Med Sci. 1959;13:1038.

48. Ara I, Siddiqui BS, Faizi S, Siddiqui S. Structurally novel diterpenoid constituents from the stem bark of Azadirachta indica (Meliaceae). J Chem Soc Perkin 1. 1989;1 (2):343-5

49. Biswas K, Chattopadhyay I, Banerjee R, Bandyopadhyay U. Biological activities and medicinal properties of neem (Azadirachta indica). Current Science. 2002;82(11):1336-45.

50. Alzohairy MA. Therapeutics Role of Azadirachta indica (Neem) and Their Active Constituents in Diseases Prevention and Treatment. Evid Based Complemen Alternat Med. 2016;2016:7382506.

51. Mahapatra S, Young CY, Kohli M, et al. Antiangiogenic Effects and Therapeutic Targets of Azadirachta indica Leaf Extract in Endothelial Cells. Evid Based Complement Alternat Med. 2012;2012:303019

52. Chaube SK, Shrivastav TG, Tiwari M, Prasad S, Tripathi A, Pandey AK. Neem (Azadirachta indica L.) leaf extract deteriorates oocyte quality by inducing ROSmediated apoptosis in mammals. Springerplus. 2014;3:464.

\section{GRAPHICAL ABSTRACT}

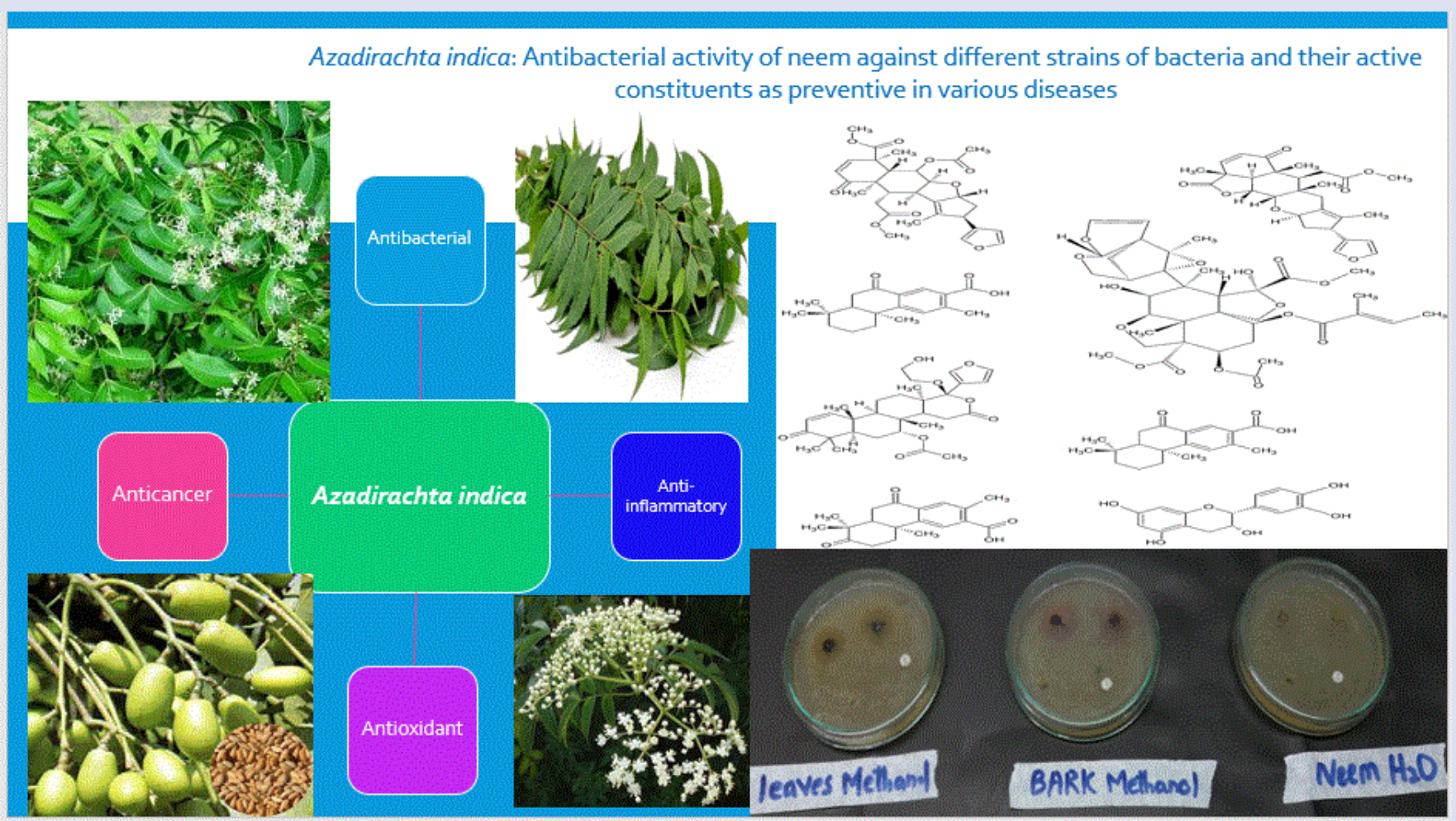




\section{ABOUT AUTHORS}

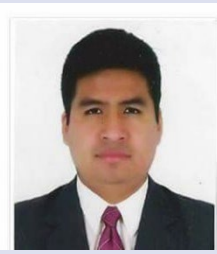

Oscar Herrera-Calderon: His expertise are natural products and the use of animals models to discover new potential drugs against different types of cancer

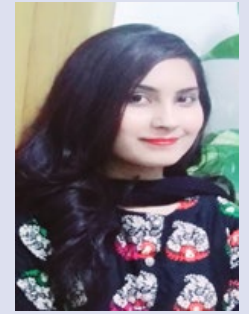

Mahnoor Wajid: She is undergraduate student in Department of Biotechnology and also doing research on medicinal plants at University of Central Punjab, Lahore, Pakistan.

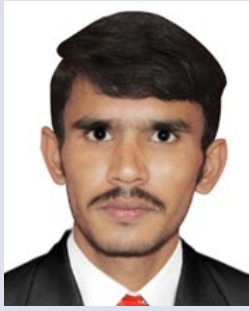

Muzzamil Shehzad: He is a final year student of B.Sc. (Hons.) Biotechnology and also works in the Biotechnology Laboratory at Faisalabad Institute of Research, Science and Technology, Pakistan.

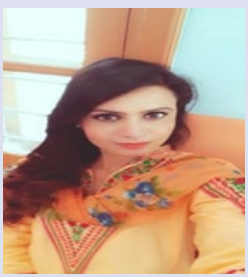

Kainat Ejaz: She graduated from Department of Biochemistry at Sardar Bahadur Khan Women's University, Balochistan, Pakistan in 2019. During her research, she worked on antibacterial activity of Medicinal plant "Azadrichta Indica" which is commonly known as Neem.

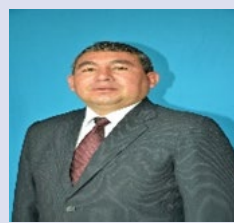

Edwin Enciso-Roca: He works in the Laboratory of toxicology, Faculty of Health Sciences, Universidad Nacional del San Cristóbal de Huamanga.

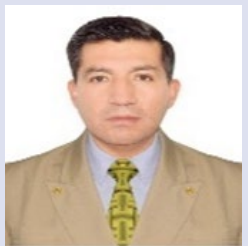

Ricardo Ángel Yuli-Posadas: He works in Universidad Continental, Huancayo, Peru.

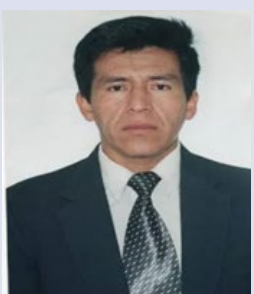

Aldo Tinco-Jayo: He works in the Laboratory of toxicology, Faculty of Health Sciences, Universidad Nacional del San Cristóbal de Huamanga. 


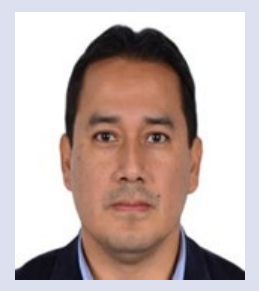

Victor Chumpitaz-Cerrate: Active Member of the International Association for Dental Research (IADR) and the International Association for the Study of Pain (IASP).

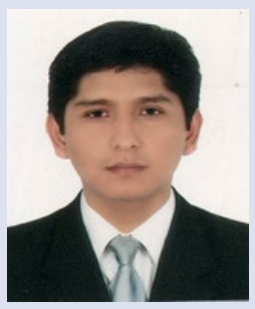

César Franco-Quino: He is studying a doctoral program in the Universidad Peruana Cayetano Heredia, Lima, Peru.

Cite this article: Herrera-Calderon O, Ejaz K, Wajid M, Shehzad M, Tinco-Jayo JA, Enciso-Roca E, et al. Azadirachta indica: Antibacterial Activity of Neem Against Different Strains of Bacteria and their Active Constituents as Preventive in Various Diseases. Pharmacog J. 2019;11(6)Suppl:1597-604. 